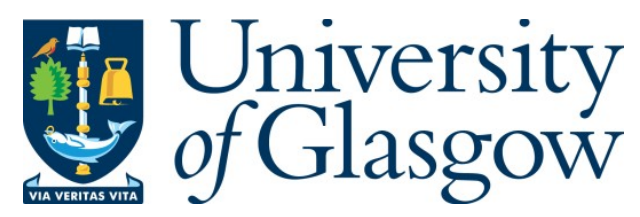

Zhang, D., Shi, X., Xu, H., Jing, Q., Pan, X., Liu, T., Wang, H. and Hou, H. (2020) A GIS-based spatial multi-index model for flood risk assessment in the Yangtze River Basin, China. Environmental Impact Assessment Review, 83, 106397.

(doi: 10.1016/j.eiar.2020.106397)

This is the Author Accepted Manuscript.

There may be differences between this version and the published version. You are advised to consult the publisher's version if you wish to cite from it.

https://eprints.gla.ac.uk/213428/

Deposited on: 6 April 2020

Enlighten - Research publications by members of the University of Glasgow http://eprints.gla.ac.uk 


\section{A GIS-based spatial multi-index model for flood risk assessment in the}

2 Yangtze River Basin, China

3

4

5

6

\section{Abstract}

This paper developed a GIS-based spatial multi-index model for the large basinscale flood risk assessment. In terms of the risk definition proposed by the IPCC, the flood risk in the Yangtze River Basin (YRB) was classified into the indexes of hazard, vulnerability, and exposure. The model systematically accounts for various flood risk indicators related to the YRB economic, social and ecological environment. Based on the ArcGIS's robust data space analysis and processing capabilities, these flood risk indicators were superimposed and analyzed to generate the integrated flood risk spatial distribution map across the YRB. The modelling results were verified reasonably well using the observed YRB floods in 1998, 2008, and 2016. We found that $24.90 \%$ of the study area was found to be of very high and high risk in 1998, while these areas in the YRB fell to $15.95 \%$ and $17.61 \%$ in 2008 and 2016, respectively. We believe that the GIS-based spatial multi-index model can be applied to other areas, where the basinscale flood risk assessment is desired, and also contribute to further scientific research on flood forecasting and mitigation.

Keywords: Flood risk assessment; Yangtze River Basin; GIS-based approach; Index system method

\section{Introduction}

In the context of global climate change, the increasingly extreme weather makes people face more significant challenges of adapting to and mitigating the adverse effects of climate change (Zeleňáková et al., 2019). Between 1995 and 2015, more than 90\% of disasters, such as floods, droughts, hurricanes, and heatwaves, were related to extreme weather (UNISDR and CRED, 2015). Among all disasters, floods have become the most common disaster, which may have more harmful effects than other disasters such as earthquakes and typhoons (Sundermann et al., 2014). The frequent occurrence of floods in various places has caused a significant upward trend in losses and impacts (Kundzewicz et al., 2014). From 1960 to 2014, floods accounted for 34\% of global natural disasters, resulting in more than $\$ 2.5$ billion in annual economic losses and 1,254 deaths per year (Petit-Boix et al., 2017). China is one of the countries with frequent floods in the world, and every major flood disaster has caused substantial economic losses. For example, in 1991, 1994, 1996 and 1998, China's flood disasters accounted for as much as 3\%-4\% of gross domestic product (GDP) (Figure 1). Since the 1990s, the annual average direct economic losses from floods accounted for $1.42 \%$ of the average annual GDP over the same period, which is almost 40 times higher than that of the United States (Wang et al., 2019). Floods have become commonplace in the 
YRB that is the largest river basin in China. Since 1860, the YRB has experienced seven massive floods (in 1860, 1870, 1931, 1935, 1954, 1998, and 2010), causing heavy casualties, material losses and social losses (Kundzewicz et al., 2019).

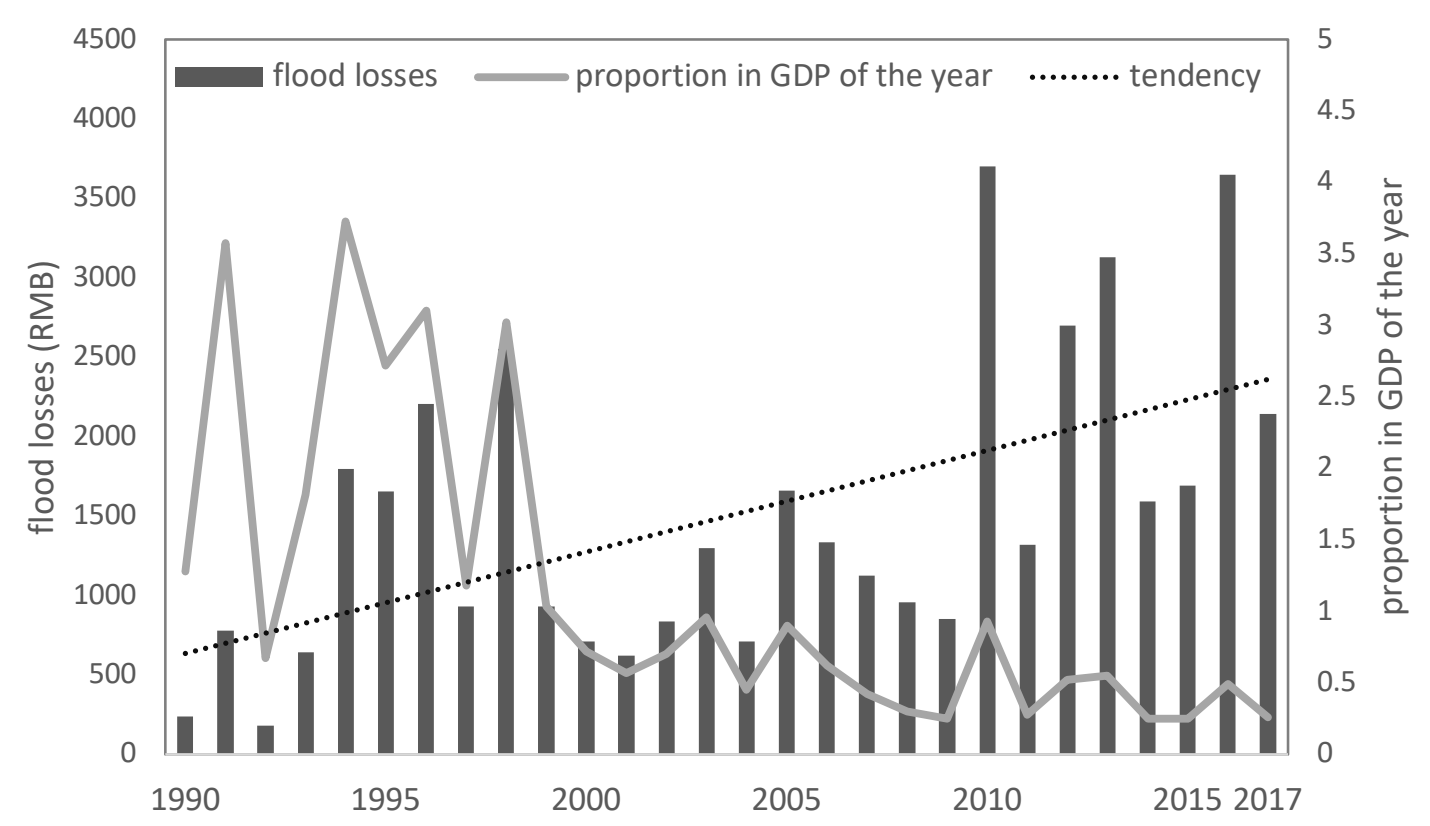

Fig. 1 Changes in total annual flood losses in China and their corresponding proportion in GDP of the year from 1990 to 2017 (data source: 2008, 2016, 2017

Bulletin of Flood and Drought Disaster in China).

It is generally believed that the factors that could cause floods are complicated and interconnected. The direct factors mainly include heavy rain, monsoon rains, tropical cyclones, snowmelt, inadequate drainage systems and structural failures of dams, brief torrential rain, tidal surge and avalanche (Halgamuge and Nirmalathas, 2017). From the definition of the causes of floods, the risk of floods should include dangerous events and trends. Besides, the prerequisites of a region (e.g., social conditions, economic conditions, and ecological conditions) could also affect the magnitude of local flood risks. The World Meteorological Organization (WMO, 1999) defines risk as "expected losses (of lives, persons injured, property damaged and economic activity disrupted) due to a particular hazard for a given area and reference period". This definition highlights the types of losses caused by the occurrence of a particular disaster. In recent years, some new challenges brought by flood disasters have emerged due to urban expansion. Floods not only caused building submerged but also entered into underground infrastructures, such as underground metro systems which have been constructed to accommodate the rapid urbanization (Lyu et al., 2018, 2019c). The UNISDR believes that disaster risk refers to the possible physical events interacting in time and space with vulnerable exposed elements of the social system (Newton and Weichselgartner, 2014). Sometimes the risk factors are more complex and vary not only because of different socio-economic conditions between regions but also because of the 
unique ecological environment of the region (Petit-Boix et al., 2017). Some researchers have tried to identify and mitigate flood risks by studying underground constructions that cause environmental and geological problems associated with long term land subsidence (Lyu et al., 2019a, 2019b) and the potential damage to groundwater or biodiversity (Brouwer and Van Ek, 2004; Kubal et al., 2009). In any case, the risks of climate-related impacts within social ecosystems have to include the hazards (hazardous events and trends), systemic vulnerability, and exposure of human and natural systems (including their adaptability) (IPCC, 2014).

In the discussion of the loss and impact of flood disasters, the methods of risk assessment have received increasing attention. It is vital to evaluate flood risk and develop risk maps for a wide range of applications, such as land-use planning and infrastructure layout. To assess flood risks, traditionally, there are four primary types of approaches used for flood risk assessment including the historical disaster statistics method (Halgamuge and Nirmalathas, 2017), index system method (Christie et al., 2018), scenario simulation analysis (Alfieri et al., 2015) and geographic information systems (GIS)-based approach (Gigović et al., 2017). Each method can independently assess flood risks, and their advantages and disadvantages are shown in Table 1.

81 However, the flood risk assessment for a large scale involving multiple indicators and 82 vast data, cannot be recognized by a single method. For effective monitoring and evaluation, the index system method should be combined with a GIS-based methodology. The index system method can consider all aspects of flood risks, while the GIS-based approach can analyze large-scale spatial data. The GIS-based research has a wide range of application in multiple assessments, such as space development (Qiao et al., 2017; Zhao et al., 2016), underground space resources evaluation (Peng and Peng, 2018a, 2018b), disaster prevention and mitigation (Cai et al., 2019). The GISbased spatial multi-index model for flood risk assessment is recognized as an effective method to identify flood risks (Abdelkarim and Gaber, 2019). 
Table 1 Four different types of evaluation approach with their advantages and disadvantages.

\begin{tabular}{|c|c|c|c|}
\hline Method & Definition & Advantages & Disadvantages \\
\hline $\begin{array}{l}\text { Historical } \\
\text { disaster } \\
\text { statistics } \\
\text { method }\end{array}$ & $\begin{array}{l}\text { Statistical analysis and evaluation of flood disaster } \\
\text { data recorded in historical documents to calculate } \\
\text { the intensity and frequency of flood disasters, and } \\
\text { based on this information to carry out the flood risk } \\
\text { and loss assessment (Van Steenbergen et al., 2012). }\end{array}$ & $\begin{array}{l}\text { Provide essential information for } \\
\text { assessment; Long time series; Many } \\
\text { disaster databases have been categorized } \\
\text { and compiled in detail. }\end{array}$ & $\begin{array}{l}\text { Requires high amounts of data; Limited by the } \\
\text { availability of historical data; Differences in the } \\
\text { way historical data recorded in different periods; } \\
\text { Statistics collection are generally based on cities, } \\
\text { and the detailed spatial variability of flood risks } \\
\text { cannot be accurately reflected. }\end{array}$ \\
\hline $\begin{array}{l}\text { Index } \\
\text { system } \\
\text { method }\end{array}$ & $\begin{array}{l}\text { Method for evaluating flood risks by selecting } \\
\text { indicators, constructing an evaluation index system, } \\
\text { and using appropriate mathematical models (Cao, } \\
\text { 2014). }\end{array}$ & $\begin{array}{l}\text { Multiple indicators of flood risks can be } \\
\text { comprehensively considered; The } \\
\text { contribution of each flood risk indicator can } \\
\text { be accurately analyzed. }\end{array}$ & $\begin{array}{l}\text { The selection of assessment indicators for flood } \\
\text { varies according to regional characteristics; Lack } \\
\text { of universal indicator system. }\end{array}$ \\
\hline $\begin{array}{l}\text { Scenario } \\
\text { simulation } \\
\text { analysis }\end{array}$ & $\begin{array}{l}\text { Based on the analysis and reasoning of changes in } \\
\text { important future influencing factors, various } \\
\text { assumptions are made by different scenarios } \\
\text { constructed to predict multiple situations occur in } \\
\text { the future (Hao, 2014). }\end{array}$ & $\begin{array}{l}\text { Provide simulations of flood risk results in } \\
\text { different scenarios; Determine the most } \\
\text { critical factors that cause flood risk changes } \\
\text { by changing some input conditions } \\
\text { (Gangrade et al., 2019). }\end{array}$ & $\begin{array}{l}\text { Affected by analytical tools and data, the accuracy } \\
\text { of the simulation is somewhat different from the } \\
\text { actual demand (Cai et al., 2019). }\end{array}$ \\
\hline $\begin{array}{l}\text { GIS-based } \\
\text { approach }\end{array}$ & $\begin{array}{l}\text { Using the spatial analysis function of } \\
\text { geoinformatics and the geostatistics module to } \\
\text { comprehensive manage and analysis of various } \\
\text { geographic data and socio-economic data which are } \\
\text { needed to identify the flood risks (Zhou et al., 2009). }\end{array}$ & $\begin{array}{l}\text { Can handle large amounts of spatial data; } \\
\text { Visualize results; Can analysis large-scale; } \\
\text { Carry out the rapid investigation. }\end{array}$ & $\begin{array}{l}\text { Cannot be used alone, it should be used with other } \\
\text { evaluation methods together. }\end{array}$ \\
\hline
\end{tabular}


A river basin is directly related to the sustainable socio-economic development and ecological security of a region or even a country, which has the highest proportion of flood occurrence. The cross-basin and cross-regional floods are defined as largescale flood disaster (Kang et al., 2006). Compared with small and medium scale flood disasters, large-scale flood disasters would cause more severe losses. Urbanization and economic growth of many cities within the flood plains have increased their exposure to the flood systems. (Komolafe et al., 2019). Therefore, it is necessary to develop effective and reliable flood risk assessment models for large river basins. This would be especially valuable for policymakers, scientists and other industry professionals to evaluate the potential risks and recognize the importance of flood mitigation and prevention.

In this paper, we aim to use an index system method and a GIS-based approach to build up a GIS-based spatial multi-index model for flood risk assessment in the YRB. In Section 2, the study area and mechanism of flood formation in this area are briefly described. In Section 3, the method is introduced in detail. Subsequently, the flood risk assessment results in the YRB are described according to the model developed in the methodology section, and the model results are verified by using the historical YRB flooding data in 1998, 2008 and 2016 in Section 4. In the final part of the paper, conclusions and discussion are provided in Section 5.

\section{Study area}

The YRB, the largest river basin in China, has a drainage area of about 1.8 million $\mathrm{km}^{2}$ (Ministry of Water Resources of the People's Republic of China, 1999). As one of the largest rivers in the world, the Yangtze River originates from the north of Tanggula Mountains of the Qinghai-Tibet Plateau and southwest side of the Gradan East Peak and flows through 11 provincial-level administrative regions (Qinghai, Tibet, Yunnan, Sichuan, Chongqing, Hubei, Hunan, Jiangxi, Anhui, Jiangsu, Shanghai). It spans more than $6300 \mathrm{~km}$ and finally flows into the East China Sea on Chongming Island in Shanghai (Chen et al., 2009). As the hundreds of tributaries can be extended to parts of the other eight provinces, it flows through 19 provincial-level administrative regions in total. The YRB accounts for $18.75 \%$ of China's total area, but with more than one-third of China's population (Liu, 2018). The lower reaches of the YRB is densely populated and economically developed. For example, the GDP of the Yangtze River Economic Zone, the most developed area in the YRB, accounts for more than a quarter of China's GDP, and its per capita GDP is 1.4 times the national average (Liu, 2018).

Topographically, the YRB is not flat, with the east low, and the west high as indicated in Figure 2. A subtropical monsoon climate dominates the YRB. Under the influence of topography and monsoon climate, the annual precipitation in the basin is unevenly distributed in time and space. Huangshan in Anhui is the area with the highest average annual precipitation $(2248.39 \mathrm{~mm})$ in the whole river basin, while the area with the lowest annual precipitation appears in Chengduo County in the upper reaches of the Yangtze River, with only $406.95 \mathrm{~mm}(\mathrm{Gu}, 2015)$. The maximum and minimum average annual precipitation differ by 4.5 times. A regular feature of floods frequently occurring in the YRB is plum rain, which lasts from June to July and coincides with the maturity of plum fruit (Jiang et al., 2008). The precipitation during rainy season generally accounts for more than $50 \%$ of annual precipitation. Sometimes, the rainy season may start earlier and last longer, and the intense and continuous rainfall begins to accumulate 
even in May and ends in September (Kundzewicz et al., 2019; Zhao et al., 2010). Abundant rainfall makes the YRB the highest flood-prone area, not only of entire China but also in Asia. The YRB in flood-prone areas, coupled with its developed economy and dense population, makes it a typical case for studying flood risks.

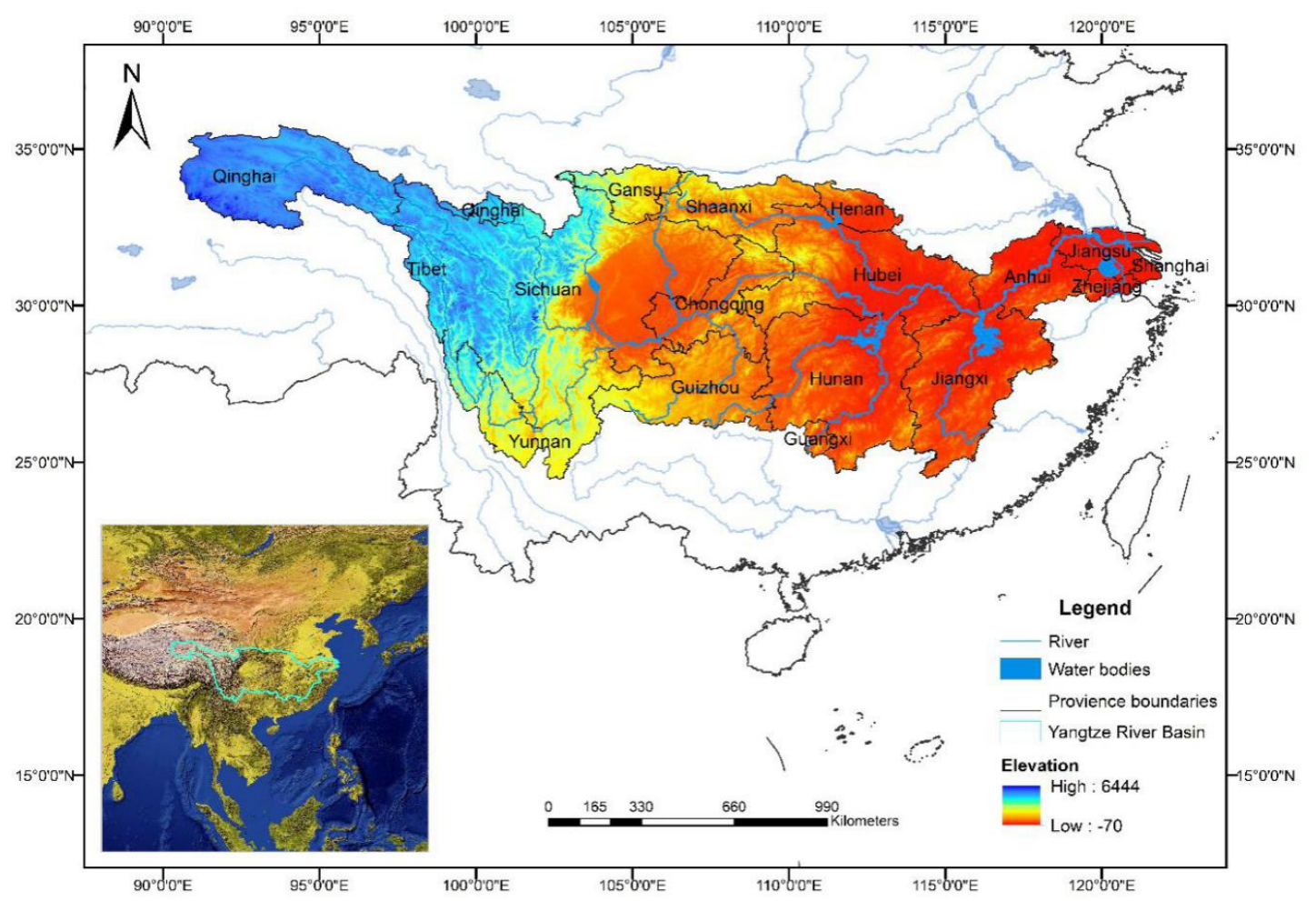

Fig. 2 Location and hydrogeographic information of Yangtze River Basin.

\section{Methodology}

\subsection{GIS-based spatial multi-index model}

This study developed a GIS-based spatial multi-index conceptual model to assess the flood risk in the YRB. Figure 3 shows the model hierarchy. The model includes two parts: (1) construction of multi-index system, and (2) analysis procedure in GIS. The multi-index system has three layers: the object layer, the index layer, and the indicator layer. The YRB flood risk (YRBFR) is the object layer; the index layer includes the hazard index $(\mathrm{H})$, vulnerability index $(\mathrm{V})$, and exposure index $(\mathrm{E})$; the indicator layer includes 13 flood risk indicators.

Data representing the 13 indicators are collected and preprocessed in the GIS environment. Then, the analytic hierarchy process (AHP) method is used to evaluate the relative importance of the various flood risk indicators. The weights of the flood risk indicators of each index layer are added together to obtain the relative importance of each index layer. The following Eq. 1 is used to redefine YRBFR.

$$
\text { YRBFR }=\mathrm{H} * W_{H}+V * W_{V}+E * W_{E}
$$

YRBFR is the Yangtze River Basin flood risk;

$\mathrm{H}$ is the hazard index; 
$\mathrm{W}_{\mathrm{H}}, \mathrm{W}_{\mathrm{E}}$ and $\mathrm{W}_{\mathrm{V}}$ are the weights of the hazard index, vulnerability index, and exposure index respectively;

To facilitate the comparison between different layers, the values of various flood risk indicators need to be normalized over the range from 0 to 1 with 5 classified levels. Then, the data for each flood risk indicator are incorporated into GIS. Finally, a risk distribution map of the YRB can be generated.

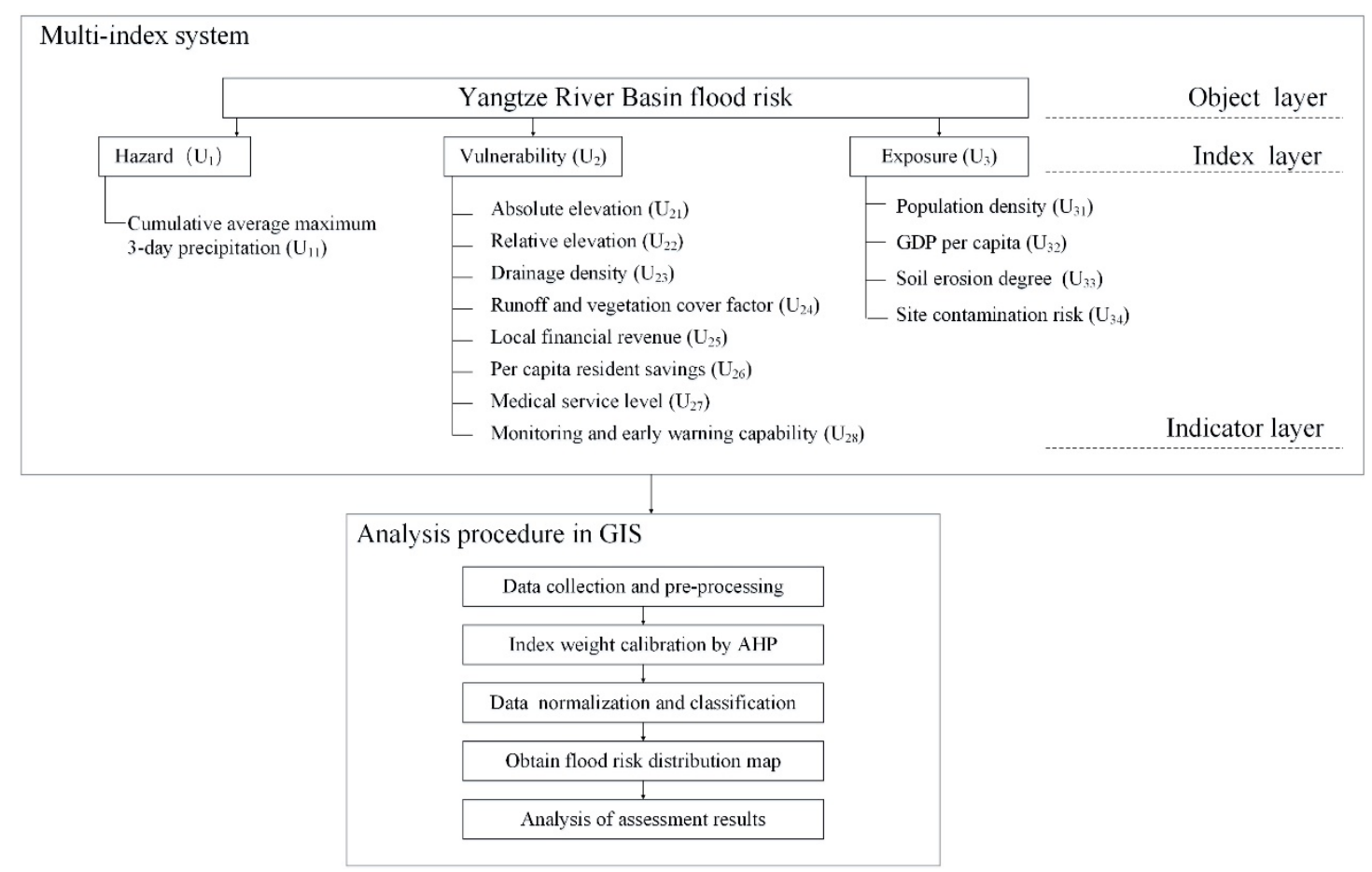

Fig. 3 Flood risk assessment model for the YRB.

\subsubsection{Multi-index system}

The critical step in establishing a multi-index system is to fill the indicator layer by defining the flood risk indicators. This article divides the index layer into hazard index, vulnerability index and exposure index following the IPCC's definition of risk. The selection of flood risk indicators mainly takes into consideration the principles of objectivity, operability, and easy spatialization. There are many natural and socioeconomic factors involved in flood risk assessment at a basin scale. It requires a detailed understanding of the risks in all parts of the basin in order to effectively divide the government responsibility for floods and conduct urban planning and disaster management. The selection of these flood risk indicators has been theoretically based on their relevance to the flood documented in the literature. Finally, the constructed YRB multi-index system is shown in Table 2.

\subsubsection{Cumulative average maximum 3-day precipitation}

There are many hazard factors directly related to flood risks. For different sections of YRB, the dominant factors are different. However, they are all directly related to precipitation. Since rainfall intensity is associated both with the frequency and the 
amount of precipitation, it is crucial to consider both values (Ouma and Tateishi, 2014; Tehrany et al., 2014a). Rainstorms in the YRB occur mostly from May to September each year, and the duration of heavy rain is generally about 3 days (Cao, 2014). Therefore, the cumulative average maximum of 3-day precipitation in the YRB from May to September is used as the hazard indicator for flood risk analyses.

\subsubsection{Absolute elevation}

Absolute elevation refers to the height difference between a certain point and sea level. In China, the average value of the height change of the sea surface of the Yellow Sea at the Qingdao Tide Station is used as the reference level of absolute elevation. The terrain is closely related to the formation of floods. The low-lying areas are more vulnerable to flooding (Cai et al., 2019). The place with higher terrain is less prone to flood disasters.

\subsubsection{Relative elevation}

In general, the difference between the absolute height of two objects is called relative elevation. In this paper, the standard deviation of $5 * 5$ grid elevations around a centre grid is used as a quantitative indicator of the terrain change of the grid. Areas with higher relative elevations have more significant gravitational acceleration and faster water velocity, which are more destructive. The slope affects the velocity in which the water is conveyed through the drainage channel and the watershed. Additionally, the steeper slopes can result in higher runoff. Consequently, higher peak discharges can be generated.

\subsubsection{Drainage density}

Drainage density refers to the ratio of the total length of the mainstream and tributary to the area of the river basin. The drainage density per unit area is the most critical basin characteristic that affects runoff. In areas with a higher density of river network, the probability of flood is higher.

\subsubsection{Runoff and vegetation cover factor}

Geomorphic types were significantly correlated with flood risk (Erpicum et al., 2010; Horritt and Bates, 2002). Different geomorphic types have different velocity coefficients and different vegetation cover. Velocity coefficient determines the amount of runoff after the precipitation reaches the surface. The faster the runoff, the higher the risk of flooding. The lusher the vegetation, the better the interception effect, which causes the slower the flow rate and the smaller the risk of flood.

\subsubsection{Local financial revenue}

The local financial support capacity is more resilient to reduce the vulnerability risk of the region. Generally speaking, the financial support capacity of a region is proportional to the government fiscal revenue and inversely proportional to the administrative area, so the per capita local financial revenue is used as an indicator of vulnerability.

\subsubsection{Per capita resident savings}

When a flood disaster occurs, residents in the disaster-stricken areas need to seize 
the opportunity to carry out self-rescue. Residents' self-rescue ability is related to their

230 financial ability to pay. Per capita resident savings is an important indicator of residents'

231 self-rescue ability assessment.

\subsubsection{Medical service level}

233

234

235

236

237

During the flood disaster, the timely medical rescue for the injured and trapped people is key to their lives. The number of hospitals, the quality of hospitals and the number of total beds can reflect the medical and health level. The smaller the population in a city, the more medical equipment the resident can be allocated. Therefore, the number of beds of one person is used to represent the medical service level of a city.

\subsubsection{Monitoring and early warning capability}

Whether there are enough hydrometeorological stations in an area to monitor rainfall and water level of rivers and lakes can greatly help to have an awareness of prevention for relevant government agencies to take appropriate preventive measures to reduce disaster losses as earlier as possible. Therefore, the hydrometeorological station density is used to represent the monitoring and early warning capability.

\subsubsection{Population density}

Zahran et al., (2008) pointed out that areas suffering more serious injuries and deaths were characterized by high population density and weak flood resistance. We used the population distribution with a spatial resolution of $1 \mathrm{~km} \times 1 \mathrm{~km}$ as an indicator to show population density.

\subsubsection{GDP per capita}

Floods of the same magnitude tend to cause far more damage in economically developed areas than in economically underdeveloped areas. In this study, GDP per capita with a $1 \mathrm{~km} \times 1 \mathrm{~km}$ resolution was selected as an indicator of exposure risk.

\subsubsection{Soil erosion degree}

Soil types of flood risk flood formation through a diversity of permeability and resistance to erosion (Barthès and Roose, 2002; Takar et al., 1990). A severe degree of land erosion can aggravate disaster evolution and result in a series of secondary disasters (debris flows, landslides). The land erosion classification data of $1 \mathrm{~km} \times 1 \mathrm{~km}$ is used to track the secondary disaster risk after the flood recedes.

\subsubsection{Site contamination risk}

Krüger et al., (2005) demonstrated that the flooding could redistribute existing soil pollutants, especially in urban areas. After the flood recedes, the pollutants carried by the flood would be more or less left in the soil, lakes and farmland, so the possibility of site contamination is also an important evaluation factor.

\subsubsection{Analysis procedure in GIS}

\subsubsection{Data sources}

Once the weights of all flood risk indicators are defined, the next step of the assessment is to collect the appropriate data to characterize indicators. Limited by the 
statistical methods of historical disaster data, most of the primary assessment units of large-scale are concentrated on an administration region. Using the administrative region can facilitate the government's flood risk management, but the statistical data obtained by the statistical yearbook is a total or average value of the statistical indicators of an area, lacking detailed information inside the administrative region, which does not reflect the spatial distribution characteristics of the flood risks ( $\mathrm{Lu}$ and $\mathrm{Wu}, 2011$ ). The rasterization of data can break the boundaries of administrative areas and reflect the spatial distribution of flood risks in more detail. Grid data has the advantage of matching and merging multiple data, which is especially suitable for the construction, realization and expression of the spatial model. Most of the index multi-source fusion algorithms in GIS are based on raster data distributed in space (Fan et al., 2006).

In this paper, a $1 \mathrm{~km} \times 1 \mathrm{~km}$ resolution is used for data calculating in GIS, and the evaluation results are expressed in grid and administrative region. Therefore, the collected data types are also divided into raster data and socio-economic statistics data. The primary data sources and data formats are shown in Table 2.

Table 2 Data source and data format.

\begin{tabular}{|c|c|c|c|c|c|}
\hline No. & Indicators & \multicolumn{3}{|l|}{ Data source } & Format \\
\hline 1 & $\begin{array}{l}\text { Cumulative average } \\
\text { maximum 3-day } \\
\text { precipitation }\end{array}$ & \multicolumn{3}{|c|}{$\begin{array}{l}\text { National Meteorological Information Center } \\
\text { (China Surface Climate Data Day Value Data } \\
\text { Set) }\end{array}$} & TXT \\
\hline 2 & Absolute elevation & $\begin{array}{l}\text { Resource and Environment } \\
\text { Platform }\end{array}$ & Data & Cloud & $\begin{array}{l}1 \mathrm{~km} \times 1 \mathrm{~km} \\
\text { raster }\end{array}$ \\
\hline 3 & Relative elevation & \multicolumn{3}{|c|}{ Calculated from absolute elevation data } & $\begin{array}{l}1 \mathrm{~km} \times 1 \mathrm{~km} \\
\text { raster }\end{array}$ \\
\hline 4 & Drainage density & $\begin{array}{l}\text { Resource and Environment } \\
\text { Platform }\end{array}$ & Data & Cloud & $\begin{array}{l}1 \mathrm{~km} \times 1 \mathrm{~km} \\
\text { raster }\end{array}$ \\
\hline 5 & $\begin{array}{l}\text { Runoff and vegetation } \\
\text { cover factor }\end{array}$ & $\begin{array}{l}\text { Resource and Environment } \\
\text { Platform }\end{array}$ & Data & Cloud & $\begin{array}{l}1 \mathrm{~km} \times 1 \mathrm{~km} \\
\text { raster }\end{array}$ \\
\hline 6 & Local financial revenue & China City Statistical Yearbook & & & PDF \\
\hline 7 & Per capita resident savings & China City Statistical Yearbook & & & PDF \\
\hline 8 & Medical service level & China City Statistical Yearbook & & & PDF \\
\hline 9 & $\begin{array}{l}\text { Monitoring and early } \\
\text { warning capability }\end{array}$ & $\begin{array}{l}\text { National Meteorological Inforn } \\
\text { China Surface Climate Data D } \\
\text { Collection }\end{array}$ & ation & $\begin{array}{l}\text { 'enter's } \\
\text { e Data }\end{array}$ & TXT \\
\hline 10 & Population density & $\begin{array}{l}\text { Resource and Environment } \\
\text { Platform }\end{array}$ & Data & Cloud & $\begin{array}{l}1 \mathrm{~km} \times 1 \mathrm{~km} \\
\text { raster }\end{array}$ \\
\hline 11 & GDP per capita & $\begin{array}{l}\text { Resource and Environment } \\
\text { Platform }\end{array}$ & Data & Cloud & $\begin{array}{l}1 \mathrm{~km} \times 1 \mathrm{~km} \\
\text { raster }\end{array}$ \\
\hline 12 & Soil erosion degree & $\begin{array}{l}\text { Resource and Environment } \\
\text { Platform }\end{array}$ & Data & Cloud & $\begin{array}{l}1 \mathrm{~km} \times 1 \mathrm{~km} \\
\text { raster }\end{array}$ \\
\hline 13 & $\begin{array}{l}\text { Site contamination risk } \\
\text { level }\end{array}$ & $\begin{array}{l}\text { Resource and Environment } \\
\text { Platform }\end{array}$ & Data & Cloud & $\begin{array}{l}1 \mathrm{~km} \times 1 \mathrm{~km} \\
\text { raster }\end{array}$ \\
\hline
\end{tabular}

3.2.1.2 Data preprocessing

The data preprocessing refers to extract the required elements from the collected real geographic data and socioeconomic data. Each indicator has been converted in the form of the spatially defined layer with a $1 \mathrm{~km} \times 1 \mathrm{~km}$ resolution. For different indicators, this study selected 6 different preprocessing strategies. All conversion processes and data preprocessing were completed using ArcGIS 10.6 software.

In order to represent the cumulative average maximum 3-day precipitation 
indicator, the coordinates of the 224 stations and cumulative rainfall data in the YRB were imported into the ArcGIS. The Kriging interpolation method was used to interpolate the point data into grid data. For the relative elevation data, the standard deviation of 25 grid elevations in the area around the centre grid was calculated as a quantitative indicator of the terrain change. The Focal Statistics tool in the ArcGIS software Spatial Analyst module was used to obtain a terrain standard difference level map. The linear density and point density calculation methods were adopted respectively to obtain the drainage density and hydrometeorological stations density distribution. In order to demonstrate the runoff and vegetation cover indicator, soil erosion degree, and site contamination risk level, this paper reclassified the $1 \mathrm{~km} \times 1 \mathrm{~km}$ land-use monitoring remote sensing data and soil erosion remote sensing data to redefine the value for each grid. The local financial revenue, per capita resident savings, and medical service level indicators were processed by connecting basic socioeconomic statistics at the city level into each $1 \mathrm{~km} \times 1 \mathrm{~km}$ grid. The raster data of absolute elevation, population density and GDP per capita were downloaded directly from the Resource and Environment Center of the Chinese Academy of Sciences.

\subsubsection{Weight calibration}

The weight of each indicator in this model is defined following the AHP, proposed by Professor T.L. Saaty in the 1970s (Saaty, 1977). As a structured technique for analyzing complex problems, the AHP involves a large number of interrelated objectives or criteria (Kazakis et al., 2015). This method is a quick-to-use method for quantifying qualitative problems. At present, the AHP has been successfully applied in the theory and practice of natural disaster risk research, and many scholars believe that the AHP in GIS environment is the most commonly used and most influential technology in producing flood risk map (Ayalew and Yamagishi, 2005; Kritikos and Davies, 2011; Lyu et al., 2019b). However, Li et al., (2013) pointed out that there are two weakness of AHP, which include the comparison matrix inconsistency and the complexity of comparison matrix pairwise construction methodology. Therefore, an improved AHP method is adopted and implemented to assess the indicators' weights through the following steps:

(1) Firstly, a hierarchical structure for the evaluation criteria factors should be established. According to the flood formation mechanism and the relationships between indicators, a hierarchical structure model is constructed for the YRB, as shown in Figure 3 (multi-index system part). From top to bottom layers, the assessment structure includes the object layer, index layer, and indicator layer.

(2) Subsequently, judgment matrix [a $\left.a_{i j}\right]$ in eq. 2 between the each indicator are used to determine the relative importance of factor ai to factor aj based on consulting expert opinions.

$$
a_{i j}=\left[\begin{array}{cccc}
a_{11} & a_{12} & \ldots & a_{1 m} \\
a_{21} & a_{22} & \ldots & a_{2 m} \\
\vdots & \vdots & \ddots & \vdots \\
a_{m 1} & a_{m 2} & \ldots & a_{m m}
\end{array}\right]
$$

The matrix should meet the following conditions:

$$
\left\{\begin{array}{c}
\sum a_{i j}=1 \\
a_{i j}=1 / a_{j i}
\end{array}(\mathrm{i}, \mathrm{j}=1,2, \ldots, \mathrm{n})\right.
$$


In order to simplify the method of constructing judgment matrix and ensure the consistency of judgment matrix, an improved questionnaire (Appendix I ) and the method of constructing judgment matrix proposed by Li et al., (2013) were adopted in this paper. This method sort all the indicators by important and assign value to the indicators by linear interpolation. The assignment method is attached in Appendix II . Nine experts from different fields were selected and fill the questionnaire. The new questionnaire have the advantages of more accurate extraction of subjective information and time savings. In this article, an indicator that can aggravate flood risk is defined as a positive indicator, while the weight is negative if the indicator has mitigation and reduction effects on flood risk.

(3) Consistency check: The consistency of judgment matrix can be validated by the value of consistency ratio (CR). It can be calculated by Eq. 4:

$$
\mathrm{CR}=\frac{C I}{R I}
$$

If the consistency ratio is less than 0.1 , it indicates that the test has passed; otherwise, the comparison matrix needs to be reconstructed. Details on the consistency test are provided in the literature (Lyu et al., 2019c, 2018a).

The final weights defined by AHP for the YRB are shown in Table 3.

Table 3 Weights of flood risk assessment indicators.

\begin{tabular}{|c|c|c|c|c|}
\hline Object layer & Index layer & $\begin{array}{l}\text { Weight } \\
\text { of the } \\
\text { index } \\
\text { layer }\end{array}$ & Indicator layer & $\begin{array}{l}\text { Weight } \\
\text { of the } \\
\text { indicator } \\
\text { layer }\end{array}$ \\
\hline \multirow{12}{*}{$\begin{array}{l}\text { Risk } \\
\text { assessment } \\
\text { of flood } \\
\text { disasters in } \\
\text { the YRB }\end{array}$} & Hazard $\left(\mathrm{U}_{1}\right)$ & \multirow[t]{5}{*}{+0.469} & Cumulative average maximum 3-day & +0.469 \\
\hline & \multirow{8}{*}{$\begin{array}{l}\text { Vulnerability } \\
\left(\mathrm{U}_{2}\right)\end{array}$} & & Absolute elevation $\left(\mathrm{U}_{21}\right)$ & -0.053 \\
\hline & & & Relative elevation $\left(U_{22}\right)$ & -0.061 \\
\hline & & & Drainage density $\left(U_{23}\right)$ & +0.039 \\
\hline & & & Runoff and vegetation cover factor $\left(\mathrm{U}_{24}\right)$ & +0.041 \\
\hline & & \multirow[t]{4}{*}{+0.322} & Local financial revenue $\left(\mathrm{U}_{25}\right)$ & -0.028 \\
\hline & & & Per capita resident savings $\left(\mathrm{U}_{26}\right)$ & -0.025 \\
\hline & & & Medical service level $\left(U_{27}\right)$ & -0.027 \\
\hline & & & $\begin{array}{l}\text { Monitoring and early warning capability } \\
\left(\mathrm{U}_{28}\right)\end{array}$ & -0.047 \\
\hline & \multirow[t]{3}{*}{$\begin{array}{l}\text { Exposure } \\
\left(\mathrm{U}_{3}\right)\end{array}$} & \multirow[t]{3}{*}{+0.209} & $\begin{array}{l}\text { Population density }\left(\mathrm{U}_{31}\right) \\
\text { GDP per capita }\left(\mathrm{U}_{32}\right)\end{array}$ & $\begin{array}{l}+0.046 \\
+0.066\end{array}$ \\
\hline & & & Soil erosion degree $\left(\mathrm{U}_{33}\right)$ & +0.068 \\
\hline & & & Site contamination risk $\left(\mathrm{U}_{34}\right)$ & +0.030 \\
\hline
\end{tabular}

\subsubsection{Normalization}

The flood risk indicators for the YRB are expressed in different units, which is difficult to compare. The way to reduce the scores to the same unit called normalization (Mohamed Elmoustafa, 2012). The basic normalization principle is to divide the difference between the actual parameter and the lowest value by the difference between the highest value and the lowest value (Eq. 5).

$$
i_{i j}=\frac{i_{\text {actual }}-i_{\min }}{i_{\max }-i_{\min }}
$$


In the GIS environment, data normalization can be realized through the Fuzzy Membership tool in Spatial Analysis module. The membership type should choose "linear", which can calculate membership based on the linear transformation for the input raster. The assigned member value of every indicator is 0 at the minimum and 1 at the maximum. All the intermediate values will get some classification values based on a linear scale. When the normalization value is closer to 1 , the flood risk is higher.

\subsubsection{Classification}

Determining the appropriate classification criteria for different risk levels is an essential step in data processing. The Jenks Natural Breaks Classification Method, proposed by Jenks and Caspall (1971), is a method of data clustering to determine the best arrangement of values in different classes, minimize variance within classes, and maximize the variance between classes. It can enhance the robustness of the model and make the nonlinear relationship between the flood risk indicators more moderate ( $\mathrm{Ji}$ et al., 2013). The Jenks Natural Breaks Classification Method uses statistical formulas (Eq. 4) to determine the natural clustering of attribute values, which reduces the difference in the same level and increases the difference between the levels (Mo et al., 2010). The similar features are assigned the same symbol to each member of the class, which can aggregate features into classes to spot patterns in the data more efficiently. All indicators are classified by using the "classified tool" in ArcGIS 10.6.

$$
S S D I_{i-j}=\sum_{k=i}^{j}\left(\mathrm{~A}[\mathrm{k}]-\operatorname{mean}_{i-j}\right)^{2},(1 \leq \mathrm{i}<\mathrm{j} \leq \mathrm{N})
$$

A is an array (the length of the array is N), $\operatorname{mean}_{i-j}$ is the average value at each level.

This study used the to classify 13 indicators, 3 indexes and the integrated flood risk into 5 levels. The classification results of the indicators data are shown in Table 4.

Table 4 Indicators data classification standard.

\begin{tabular}{|c|c|c|c|c|c|}
\hline Indicators & D1 & $\mathrm{D} 2$ & D3 & D4 & D5 \\
\hline $\begin{array}{l}\text { Cumulative average maximum } \\
\text { 3-day precipitation }(\mathrm{mm})\end{array}$ & $<777$ & $777-1308$ & $\begin{array}{c}1308- \\
1868\end{array}$ & $1868-2522$ & $>2523$ \\
\hline Absolute elevation (m) & $\begin{array}{l}-70- \\
633\end{array}$ & $633-1569$ & $\begin{array}{l}1569- \\
2820\end{array}$ & $2820-4064$ & $\begin{array}{l}4064- \\
6444\end{array}$ \\
\hline Relative elevation (m) & $0-57$ & $57-132$ & $132-219$ & 219-332 & $332-961$ \\
\hline Drainage density & $0-5.4$ & $5.4-9.8$ & $9.8-18.0$ & $18.0-33.7$ & $33.7-62.7$ \\
\hline $\begin{array}{l}\text { Runoff and vegetation cover } \\
\text { factor }\end{array}$ & $0-0.2$ & $0.2-0.4$ & $0.4-0.6$ & $0.6-0.8$ & $0.8-1.0$ \\
\hline $\begin{array}{l}\text { Local financial revenue } \\
\left(10000 \mathrm{yuan} / \mathrm{km}^{2}\right)\end{array}$ & $<11$ & $11-54$ & $54-193$ & $193-354$ & $>354$ \\
\hline $\begin{array}{l}\text { Per capita resident savings } \\
\text { (yuan/person) }\end{array}$ & $\begin{array}{l}3466- \\
16132\end{array}$ & $\begin{array}{l}16132- \\
26522\end{array}$ & $\begin{array}{c}26522- \\
44156\end{array}$ & $44156-73065$ & $\begin{array}{l}73065- \\
162060\end{array}$ \\
\hline $\begin{array}{l}\text { Medical service level (bed } \\
\text { space/person) }\end{array}$ & $<12$ & $12-19$ & $19-27$ & $27-37$ & $>37$ \\
\hline $\begin{array}{l}\text { Monitoring and early warning } \\
\text { capability }\end{array}$ & $0-1.91$ & $1.91-4.31$ & $4.31-5.98$ & $5.98-8.38$ & $\begin{array}{l}8.38- \\
12.20\end{array}$ \\
\hline $\begin{array}{l}\text { Population density } \\
\left(\text { person } / \mathrm{km}^{2}\right)\end{array}$ & $<308$ & $308-328$ & $328-637$ & $637-5433$ & $>5433$ \\
\hline GDP per capita (yuan $/ \mathrm{km}^{2}$ ) & $<27$ & $27-480$ & $480-7836$ & $7836-127401$ & $>127401$ \\
\hline Soil erosion degree & $0-0.43$ & $0.43-0.76$ & $0.76-1.19$ & $1.19-1.76$ & $1.76-2.5$ \\
\hline Site contamination risk & $0-0.2$ & $0.2-0.4$ & $0.4-0.6$ & $0.6-0.8$ & $0.8-1.0$ \\
\hline Hazard risk & $0-0.17$ & $0.17-0.32$ & $0.32-0.48$ & $0.48-0.67$ & $0.67-1.0$ \\
\hline
\end{tabular}




\begin{tabular}{llllll}
\hline Vulnerability risk & $0-0.36$ & $0.36-0.45$ & $0.45-0.53$ & $0.53-0.61$ & $0.61-1.0$ \\
Exposure risk & $0-0.17$ & $0.17-0.23$ & $0.23-0.30$ & $0.30-0.53$ & $0.53-1.0$ \\
Integrated flood risk & $0-0.18$ & $0.18-0.31$ & $0.31-0.45$ & $0.45-0.61$ & $0.61-1.0$ \\
\hline
\end{tabular}

\section{Results}

After the procedure of the selection of indicators, we pre-processed, normalized and classified their data in the GIS environment and obtained the spatial distribution map of each flood risk indicator. The spatial distribution maps for flood risk indicators are shown in Figure 4 by taking the year 2016 as an example. The spatial distribution maps for the years of 1998 and 2008 are provided in the appendix because of the space limits. The Raster Calculator of Map Algebra tool in Spatial Analyst module is used to overlay the indicators and index layers according to their weights. Hazard, vulnerability, exposure and integrated flood risk distribution map of the YRB, as shown respectively in Figures 5, 6, 7, and 8. 


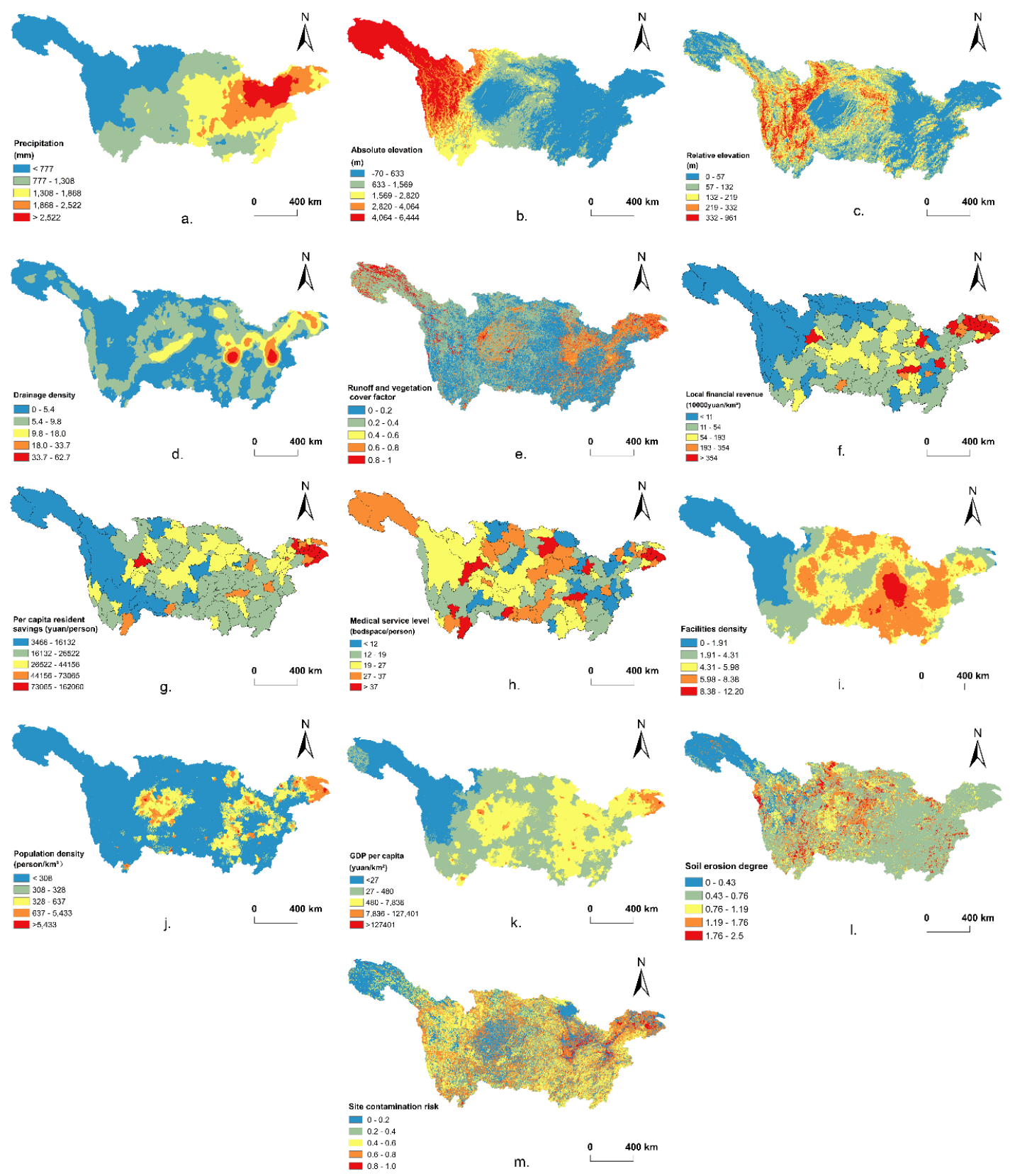

394 Fig. 4 Spatial distribution maps for 13 indicators in the YRB: (a) Cumulative average maximum of 3-day precipitation; (b) Absolute elevation; (c) Relative elevation; (d) Drainage density; (e) Runoff and vegetation cover factor; (f) Local financial revenue; (g) Per capita resident savings; (h) Medical service level; (i) Monitoring and early warning capability; (j) Population density; (k) GDP per capita; (l) Soil erosion degree; (m) Site contamination risk level.

\subsection{Hazard assessment}

Hazard is an index layer with the most significant weight, which largely determines the flood risk evaluation results. The hazard risk mainly comes from the cumulative average maximum of 3-day precipitation. In the temporal distribution of rainfall, judging from 1998, 2008, 2016 hazard risk map (Figure 5), the interannual variation of rainfall is relatively large. It is worth noting that the severity of floods in 
an area is directly related to the hazard level. Lateral comparing the risk findings in 1998, 2008, and 2016, there were more high-risk areas in 1998 and less high-risk areas in 2008. The spatial distribution of precipitation in the YRB shows a trend of less in the west and more in the east, with distinct stratification and uneven spatial variations. The main high-risk and very high-risk areas are in the middle and lower reaches of the YRB, such as Anhui, Hunan, Hubei, Jiangsu, Jiangxi, and Zhejiang. In the upper reaches of the YRB, there is less rainfall and less hazard risk.

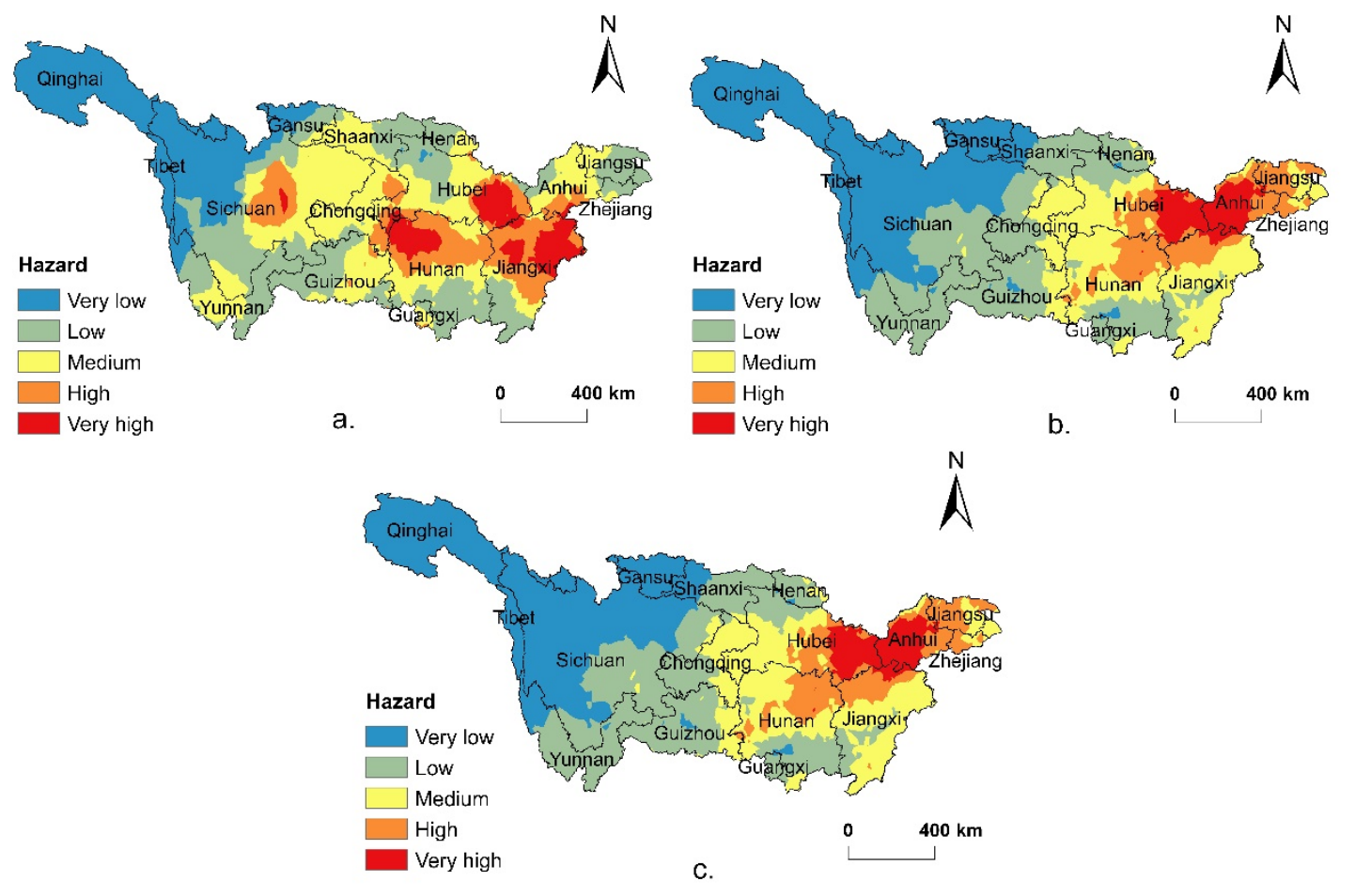

Fig. 5 Spatial distribution maps of hazard levels: (a) 1998; (b) 2008; (c) 2016.

\subsection{Vulnerability assessment}

The spatial distribution maps of vulnerability in the YRB are shown in Figure 6. The areas adjacent to river and lake banks, such as in parts of the border between Hunan and Hubei, as well as Jiangxi and Anhui, were found in very-high vulnerability risk where the Dongting Lake and the Poyang Lake are in these areas. In addition, there are some very high-risk areas in the Sichuan Basin because the absolute elevation and relative elevation of the area are both low, which makes the flood difficult to discharge but easy to accumulate. In parts of Qinghai, the rescue ability of local government and residents is weak when the disaster arrives, due to low local financial revenue, per capita resident savings, and medical service level.

From 1998 to 2016, the spatial vulnerability distribution changes a little, but the area with high vulnerability risk is gradually decreasing, which is conform to the actual situation of the YRB. The indicators of absolute elevation, relative elevation, and drainage density change little with the years. However, the vegetation coverage in the YRB has significantly changed in the past 20 years. Except for the decline of vegetation cover in the upper reaches of the YRB, most of the YRB tends to increase the vegetation coverage. The vegetation coverage growth can enhance the infiltration rate of 
precipitation and slow down flood runoff, thereby reducing the flood vulnerability of these areas. Besides, with the rapid development of the economy in the YRB, the government and local people have more funds available for disaster relief and casualties reduction.

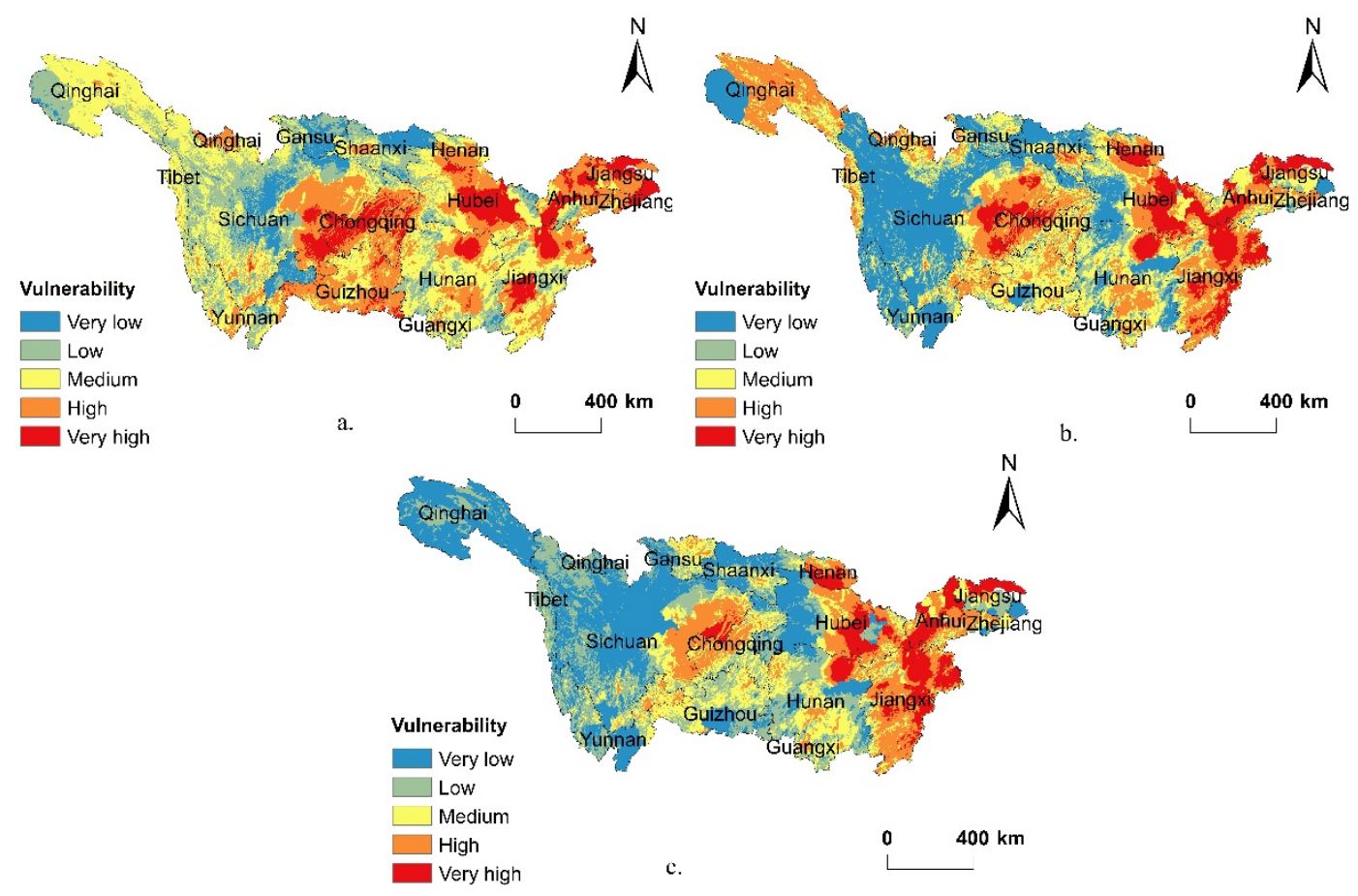

Fig. 6 Spatial distribution maps of vulnerability levels: (a) 1998; (b) 2008; (c) 2016.

\subsection{Exposure assessment}

The spatial distribution of YRB flood risk exposure is characterized by high in the southeast and low in the northwest, increasing slightly over time, as shown in Figure 7. The highly exposed areas of the YRB are mainly distributed in the southeastern part of the YRB and the eastern coastal areas. These regions have a large population density and economic value of a unit of land. A typical example is the Yangtze River Delta region (part of Shanghai and Jiangsu and Zhejiang). Due to the dense population of the low-lying and broad valleys in the lower reaches, once the floods come, it would cause substantial economic losses in flood events (Kundzewicz et al., 2019). In most areas of Yunnan, Guizhou, Gansu and some other places, there are also many high-risk areas because of soil erosion and unique terrain. With the loss of surface water and soil, shallow landslides are easily formed in the gully slopes during rainfall, thus increasing the risk of secondary disasters, such as mudslide and landslides (Zhou, 2013). 


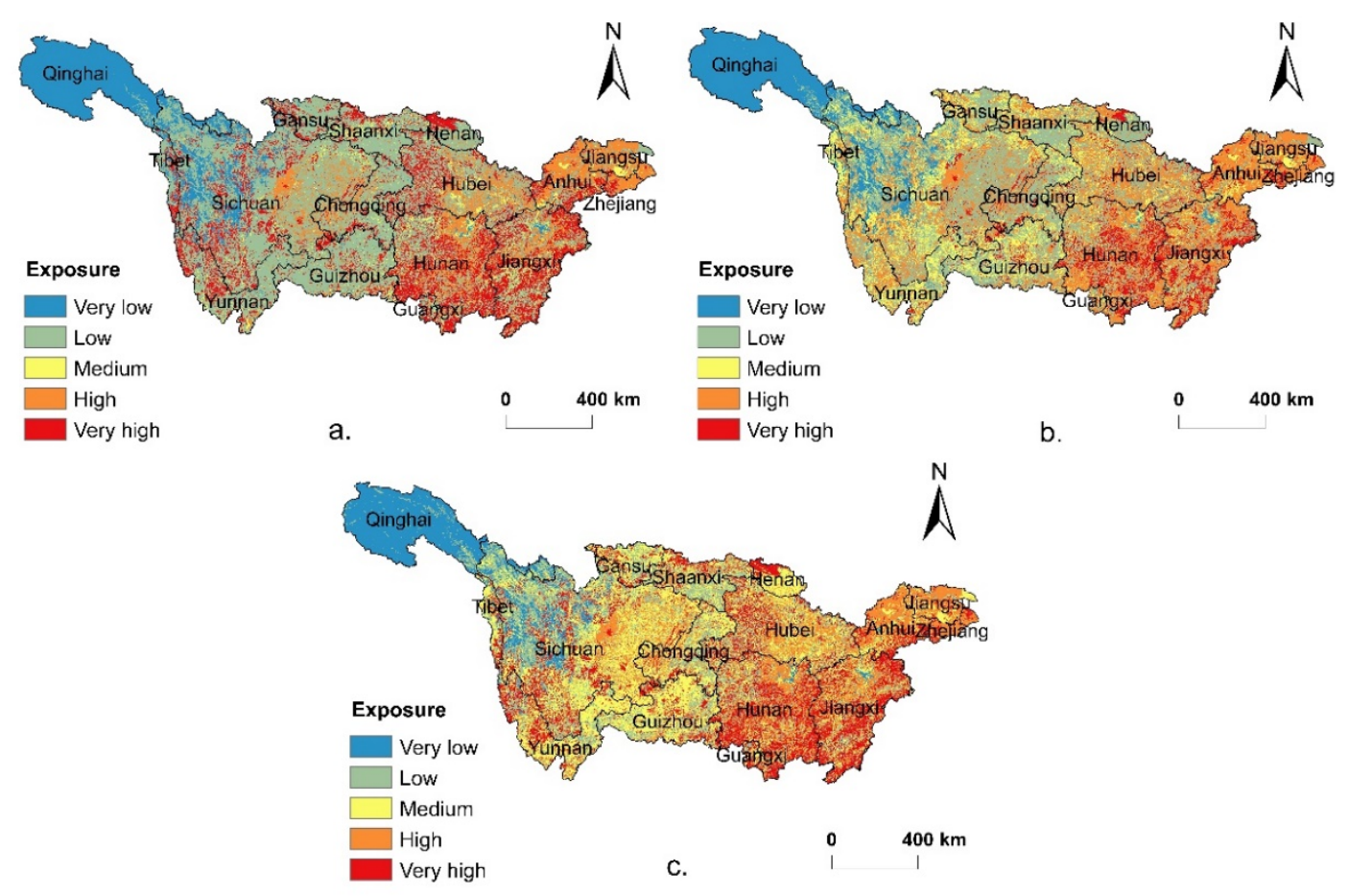

452

Fig. 7 Spatial distribution maps of exposure levels: (a) 1998; (b) 2008; (c) 2016.

\subsection{Integrated flood risk assessment}

Based on the hazard, vulnerability and exposure spatial distribution map, the three layers are superimposed to obtain an integrated assessment result as shown in Figure 8.

After using the raster to the point tool, the value of each $1 * 1 \mathrm{~km}$ grid is generated, and the proportions of areas with different risk levels in the YRB can be calculated. Five categories of integrated flood risk were distinguished: very low, low, medium, high and very high in Table 5.

Table 5 Integrated flood risk distribution in the YRB.

\begin{tabular}{llll}
\hline Risk level & 1998 & 2008 & 2016 \\
\hline Very high risk & $11.07 \%$ & $8.65 \%$ & $7.52 \%$ \\
High risk & $13.83 \%$ & $7.30 \%$ & $10.09 \%$ \\
Medium risk & $23.72 \%$ & $19.57 \%$ & $15.91 \%$ \\
Low risk & $27.57 \%$ & $23.45 \%$ & $28.70 \%$ \\
Very low risk & $26.81 \%$ & $43.03 \%$ & $40.78 \%$ \\
\hline
\end{tabular}

In $1998,24.90 \%$ of the study area was found to be of very high and high risk, while these areas in the YRB fell to $15.95 \%$ and $17.61 \%$ in 2008 and 2016 , respectively. Very low-risk zones made up $24.89 \%$ in 1998 , while these areas in the YRB reached up to $66.48 \%$ and $69.48 \%$ in 2008 and 2016 respectively. The integrated risk of the YRB is closely related to the magnitude of the hazard because of 
its significant weight. In the middle and lower reaches of the YRB (Anhui, southern Jiangsu, eastern Hubei), the eastern coastal areas, and the areas in Chongqing and Sichuan are found in very high-risk and high-risk flood zones. Most of the central mountainous areas of the YRB have medium flood risks, mainly due to flash floods caused by heavy rainfall in a short period. The low-risk and very low-risk areas of flood disasters in the YRB are mainly concentrated in the western part of the YRB. Due to the small impact of the typhoon in the western region, the rainfall is low, and the terrain is dominated by the plateau, which is not prone to floods. In the middle of the YRB, the integrated risk gradually decreases with years, mainly because the regional vulnerability has become less sensitive with the development of economic society.

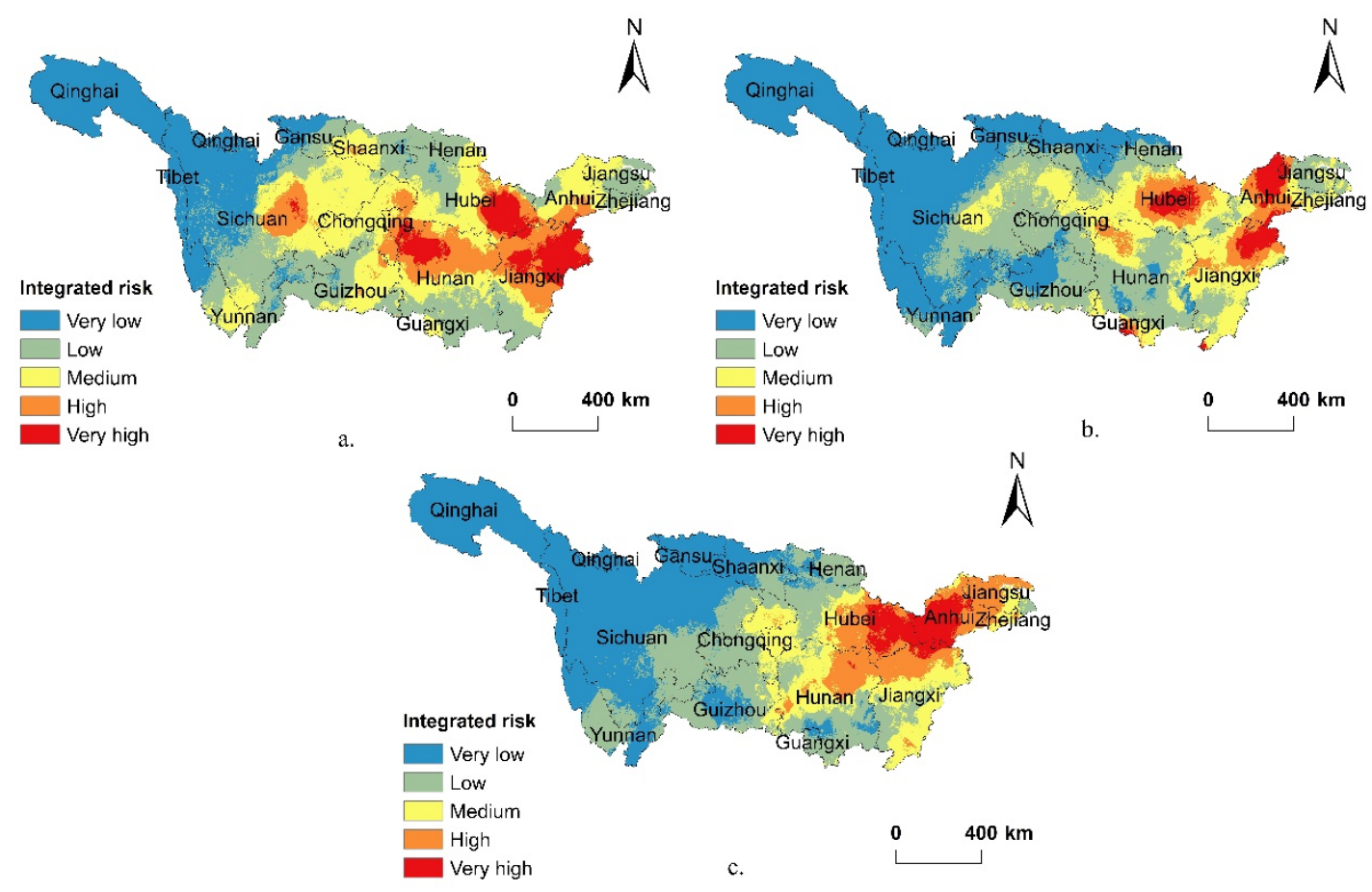

478

Fig. 8 Integrated risk spatial distribution maps: (a) 1998; (b) 2008; (c) 2016.

\subsection{Validation}

Historical floods observed data in 1998, 2008, and 2016 of the YRB for rainfall, inundation area, and economic losses are used in this section to verify the veracity of the evaluation results. The YRB experienced severe floods in 1998 and 2016 because of the El Nino periods based on recorded data (Lyu et al., 2018b). In order to verify the model's reliability under different flood levels, the 2008 small floods in the YRB are used here as a comparison between 2016 and 2008 historical floods.

A catastrophic flood in the YRB occurred in 1998, covering a wide range, lasting a long time, and causing severe economic losses, which is consistent with the assessment results. The leading causes of floods in 1998 are excessive heavy rains, reduced storage capacity of rivers and lakes, destroyed the ecological balance, low vegetation coverage, and low flood relief ability ( $\mathrm{Li}, 1999$; Zhao et al., 2000). In Figure 5(a), the cumulative maximum 3-day precipitation in high-risk areas of the YRB 
exceeded $2,500 \mathrm{~mm}$. Nearly half of the YRB is at medium risk, with the cumulative maximum 3-day precipitation exceeding $1,300 \mathrm{~mm}$. In the hazard and vulnerability assessment, rainfall in the YRB was the highest in 1998, 2008, and 2016, and vegetation coverage was the lowest in those years. It is consistent with the real situation. In addition, the high-risk areas in the vulnerability risk map of the YRB in 1998 were higher than in 2016. Therefore, although a catastrophic flood also occurred in 2016, the proportion of economic losses in the year's GDP was much less than in 1998 as indicated in Figures 8(a) and 8(c).

Compared with 1998, the high-risk areas decreased significantly in 2008. Actually, during the flood season from May to September in 2008, compared to 1998 and 2016, most parts of China experienced less continuous precipitation (State Flood Control and Drought Relief Ministry of Water Resources of the People's Republic of China, 2008). During the 2008 flood season, there were no massive floods in the mainstream of the YRB, but the floods in some tributaries exceeded the warning level, which is consistent with the assessment results in Figure 5. In 2008, floods occurred frequently, and the loss distribution was concentrated, but it was lighter than the average for many years. The provinces of Guangdong, Guangxi, Hunan, Hubei, Zhejiang, Jiangxi, Anhui, Sichuan, Yunnan and other autonomous regions were severely affected but compared with the average for years, the flood disaster area was $363 \%$ less, the death toll was $77.3 \%$ less, and the total direct economic loss was $152 \%$ less. As a result, the integrated risk for 2008 was at a low level in comparison with 1998 and 2016.

In the assessment results of the flood disaster risk in the YRB in 2016, the highrisk areas were significantly lower than in 1998 and 2008. In fact, in 2016, the YRB experienced the second-highest flood since 1998 (State Flood Control and Drought Relief Ministry of Water Resources of the People's Republic of China, 2016). However, the economic losses caused by the 2016 floods as a percentage of annual GDP were much smaller than that in 1998 (Figure 1). In the 2016 vulnerability assessment, the economic losses after the flood in the middle and lower reaches of the YRB were reduced after the ability of the YRB to respond to disasters increased.

In summary, the model has been proved to be reliable, and the risk evaluation results can be more accurately displayed in terms of the risk indexes of hazard, vulnerability and exposure, as well as the integrated flood risk.

\section{Conclusions and discussion}

The paper has presented an integrated approach (GIS-based spatial multi-index model) for large basin-scale flood risk mapping and assessment. In order to investigate the overall impacts (economic, social, and environment) of the flood and describe the flood risk spatial distribution as accurate as possible, an index system method and a GIS-based approach were used. Finally, the results were verified using the YRB observed floods in 1998, 2008, and 2016. The conclusions are summarized as follows:

(1) The flood risk in the YRB is mainly related to precipitation. The GDP per capita, surface runoff factor, and vegetation coverage, local financial revenue, and erosion degree also play a relatively important role.

(2) The northeastern part of the YRB was found in the integrated very high-risk and high-risk areas in the YRB. The hazard risks vary significantly over the years, while the vulnerability and exposure risks change relatively less with time. 
(3) Results were verified using observed floods in the YRB in 1998, 2008, and 2016. It has been proved as a replicable approach for large-scale flood risk assessment, especially for the assessment at a basin scale.

Compared with small and medium-scale flood disasters, floods across basins and regions could result in significant losses and huge impacts. Large-scale flood risk assessment requires a detailed investigation of natural geographic information such as topographical terrain, characteristics of flood disasters, and socio-economic losses, with enormous human and financial costs (Cao, 2014). Therefore, the research often focuses on specific flood-prone areas, such as coastal area, metro systems, reservoirs; Or in the administrative area, a county, city or province. Risk assessment in a larger area is likely to result in a decrease in the assessment accuracy and more generalized indicators. However, the $1 \mathrm{~km} * 1 \mathrm{~km}$ grid is used in this risk assessment to improve the spatial resolution of prediction results. If the detailed analysis of potential flood risk indicators affecting a particular area is needed, the spatial distribution maps can be performed according to each of the provided indicators, and actual investigations are made on the advice of decision-makers.

The main advantage of this approach is that it can successfully provide a comprehensive indicator selection proposal for the large-scale, especially basin-scale flood risk assessment that can be processed by a complete set of GIS tools to achieve the visualization. During the application of the risk assessment model, there are some challenges, such as data availability and quality to represent indicators including precipitation, land economy social value, or the vulnerability of the site to contamination for the specific regional context. Therefore, additional efforts are needed to produce a considerable enhancement in term of careful consideration for indicators, data availability and quality. For future research work on the large-scale flood assessment, there are two possible ways to improve. Firstly, to improve the accuracy for flood risk assessments, high precision raw data sets should be adopted, and a new sound quality weighting system for indicators should be built up. Secondly, in order to apply the conceptual model in the actual processes of flood risk mitigation and adaptation, the field research and assessment results should include policy advice. \\ 568 Appendix I}

569 Using the questionnaire, an example of results are shown as follows

570 Elements $\mathrm{U}_{1} \quad \mathrm{U}_{2} \quad \mathrm{U}_{3}$

571 Sort order (2) (1) (3)

\section{Appendix II}

573 Table 1 Value assessment of sorted elements

\begin{tabular}{ccccccccc}
\hline $\begin{array}{c}\text { Number } \\
\text { of } \\
\text { element } \\
\text { s }\end{array}$ & $\begin{array}{c}\text { Value } \\
\text { of 1st } \\
\text { element }\end{array}$ & $\begin{array}{c}\text { Value } \\
\text { of 2nd } \\
\text { element }\end{array}$ & $\begin{array}{c}\text { Value } \\
\text { of 3rd } \\
\text { element }\end{array}$ & $\begin{array}{c}\text { Value } \\
\text { of 4th } \\
\text { element }\end{array}$ & $\begin{array}{c}\text { Value } \\
\text { of 5th } \\
\text { element }\end{array}$ & $\begin{array}{c}\text { Value } \\
\text { of 6th } \\
\text { element }\end{array}$ & $\begin{array}{c}\text { Value } \\
\text { of 7th } \\
\text { element }\end{array}$ & $\begin{array}{c}\text { Value } \\
\text { of 8th } \\
\text { element }\end{array}$ \\
\hline 3 & 10 & 6 & 1 & & & & & \\
4 & 10 & 7 & 4 & 1 & & & \\
\hline
\end{tabular}




\begin{tabular}{lllllllll}
\hline 5 & 10 & 8 & 6 & 3 & 1 & & & \\
6 & 10 & 8 & 6 & 5 & 3 & 1 & & \\
7 & 10 & 9 & 7 & 6 & 4 & 3 & 1 & \\
8 & 10 & 9 & 7 & 6 & 5 & 4 & 2 & 1 \\
\hline
\end{tabular}

Note: According to the importance arrangement, the value of the most important element is 10 , and the least important one is 1 . By using this table, the values of the indicators can be assigned by linear interpolation.

An example of the results are shown as follows:

Table 2 Sorting comparisons matrix

\begin{tabular}{llll}
\hline & $\mathrm{U}_{1}$ & $\mathrm{U}_{2}$ & $\mathrm{U}_{3}$ \\
\hline $\mathrm{U}_{1}$ & 1 & $1 / 4$ & 5 \\
$\mathrm{U}_{2}$ & 4 & 1 & 9 \\
$\mathrm{U}_{3}$ & $1 / 5$ & $1 / 9$ & 1 \\
\hline
\end{tabular}

\section{Reference}

Abdelkarim, A., Gaber, A.F.D., 2019. Flood risk assessment of the Wadi Nu'man basin, Mecca, Saudi Arabia (during the period, 1988-2019) based on the integration of geomatics and hydraulic modeling: A case study. Water (Switzerland) 11. https://doi.org/10.3390/w11091887

Alfieri, L., Feyen, L., Dottori, F., Bianchi, A., 2015. Ensemble flood risk assessment in Europe under high end climate scenarios. Glob. Environ. Chang. 35, 199-212. https://doi.org/10.1016/j.gloenvcha.2015.09.004

Ayalew, L., Yamagishi, H., 2005. The application of GIS-based logistic regression for landslide susceptibility mapping in the Kakuda-Yahiko Mountains, Central Japan. Geomorphology. https://doi.org/10.1016/j.geomorph.2004.06.010

Barthès, B., Roose, E., 2002. Aggregate stability as an indicator of soil susceptibility to runoff and erosion; validation at several levels. Catena. https://doi.org/10.1016/S0341-8162(01)00180-1

Cai, T., Li, X., Ding, X., Wang, J., Zhan, J., 2019. Flood risk assessment based on hydrodynamic model and fuzzy comprehensive evaluation with GIS technique. Int. J. Disaster Risk Reduct. https://doi.org/10.1016/j.ijdrr.2019.101077

Cao, L., 2014. Research on the Assessment of Flood and Waterlogging Risk in the Zhejiang Province Based on Remote Sensing and Geographic Information System. Ningbo University. (in Chinese)

Chen, M., Shen, H., Shi, G., 2009. Construction of flood control and drought relief system in the Yangtze River Basin. China Flood Drought Manag. A01, 153-164.

Christie, E.K., Spencer, T., Owen, D., McIvor, A.L., Möller, I., Viavattene, C., 2018. Regional coastal flood risk assessment for a tidally dominant, natural coastal setting: North Norfolk, southern North Sea. Coast. Eng. https://doi.org/10.1016/j.coastaleng.2017.05.003

Erpicum, S., Dewals, B., Archambeau, P., Detrembleur, S., Pirotton, M., 2010. Detailed Inundation Modelling Using High Resolution DEMs. Eng. Appl. Comput. Fluid Mech. https://doi.org/10.1080/19942060.2010.11015310

Fan, Y., Shi, P., Gu, Z., Li, X., 2006. A Method of Data Gridding from Administration Cell to Gridding Cell. Sci. Geogr. Sin. 01, 105-108. (in Chinese)

Gangrade, S., Kao, S.C., Dullo, T.T., Kalyanapu, A.J., Preston, B.L., 2019. Ensemble-based flood vulnerability assessment for probable maximum flood in a changing environment. J. Hydrol. 576, 342-355. https://doi.org/10.1016/j.jhydrol.2019.06.027

Gigović, L., Pamučar, D., Bajić, Z., Drobnjak, S., 2017. Application of GIS-interval rough AHP methodology for flood hazard mapping in Urban areas. Water (Switzerland) 9, 1-26. https://doi.org/10.3390/w9060360

$\mathrm{Gu}$, H., 2015. Study on precipitation characteristics and its relationship with the flood in the Yangtze River Catchment. Nanjing University of Information Science and Technology. (in Chinese)

Halgamuge, M.N., Nirmalathas, A., 2017. Analysis of large flood events: Based on flood data during 1985-2016 in Australia and India. Int. J. Disaster Risk Reduct. https://doi.org/10.1016/j.ijdrr.2017.05.011

Hao, D., 2014. Risk Assessment and Scenario Analysis of Flood Disaster in Chaohu Lake Basin. Anhui Normal University. (in Chinese)

Horritt, M.S., Bates, P.D., 2002. Evaluation of 1D and 2D numerical models for predicting river flood inundation. J. Hydrol. https://doi.org/10.1016/S0022-1694(02)00121-X

IPCC, 2014. Climate Change 2014, Climate Change 2014: Synthesis Report. 
Jenks, G.F., Caspall, F.C., 1971. Error on Choroplethic Maps : Definition, Measurement, Reduction. Ann. Assoc. Am. Geogr. 61, 217-244. https://doi.org/10.1111/j.1467-8306.1971.tb00779.x

Ji, Z., Li, N., Xie, W., Wu, J., Zhou, Y., 2013. Comprehensive assessment of flood risk using the classification and regression tree method. Stoch. Environ. Res. Risk Assess. https://doi.org/10.1007/s00477-013-0716-Z

Jiang, T., Kundzewicz, Z.W., Su, B., 2008. Changes in monthly precipitation and flood hazard in the Yangtze River Basin, China. Int. J. Climatol. https://doi.org/10.1002/joc.1635

Kang, X., Wu, S., Dai, E., Yang, Q., Liu, Z., Yang, P., Ma, X., Zhao, R., 2006. Pre-assessment of large-scale flood disaster losses and impacts. Chinese Sci. Bull. 51, 155-164. (in Chinese)

Kazakis, N., Kougias, I., Patsialis, T., 2015. Assessment of flood hazard areas at a regional scale using an indexbased approach and Analytical Hierarchy Process: Application in Rhodope-Evros region, Greece. Sci. Total Environ. 538, 555-563. https://doi.org/10.1016/j.scitotenv.2015.08.055

Komolafe, A.A., Herath, S., Avtar, R., 2019. Establishment of detailed loss functions for the urban flood risk assessment in Chao Phraya River basin, Thailand. Geomatics, Nat. Hazards Risk 10, 633-650. https://doi.org/10.1080/19475705.2018.1539038

Kritikos, T., Davies, T.R.H., 2011. GIS-based multi-criteria decision analysis for landslide susceptibility mapping at northern Evia, Greece. Zeitschrift der Dtsch. Gesellschaft fur Geowissenschaften. https://doi.org/10.1127/1860-1804/2011/0162-0421

Krüger, F., Meissner, R., Gröngröft, A., Grunewald, K., 2005. Flood induced heavy metal and arsenic contamination of Elbe river floodplain soils. Acta Hydrochim. Hydrobiol. https://doi.org/10.1002/aheh.200400591

Kundzewicz, Z.W., Kanae, S., Seneviratne, S.I., Handmer, J., Nicholls, N., Peduzzi, P., Mechler, R., Bouwer, L.M., Arnell, N., Mach, K., Muir-Wood, R., Brakenridge, G.R., Kron, W., Benito, G., Honda, Y., Takahashi, K., Sherstyukov, B., 2014. Flood risk and climate change: global and regional perspectives. Hydrol. Sci. J. https://doi.org/10.1080/02626667.2013.857411

Kundzewicz, Z.W., Su, B., Wang, Y., Xia, J., Huang, J., Jiang, T., 2019. Flood risk and its reduction in China. Adv. Water Resour. 130, 37-45. https://doi.org/10.1016/j.advwatres.2019.05.020

Li, A., 1999. 1998 Yangtze flood and fight against it. YANGTZE RIVER 3-9+57. https://doi.org/DOI:10.16232/j.cnki.1001-4179.1999.01.002

Li, F., Phoon, K.K., Du, X., Zhang, M., 2013. Improved AHP method and its application in risk identification. J. Constr. Eng. Manag. https://doi.org/10.1061/(ASCE)CO.1943-7862.0000605

Liu, F., 2018. A Study on Extreme Precipitation Events and Population Exposure under the Different Scenarios of Warming over the Yangzte River Basin. Nanjing University of Information Science and Technology. (in Chinese)

Lu, K., Wu, J., 2011. Research on Grid Transformation Model of Statistical Data Based on source Information Fusion. J. Zhejiang Water Conserv. Hydropower Coll. 23, 55-58. (in Chinese)

Lyu, H.M., Shen, J.S., Arulrajah, A., 2018a. Assessment of geohazards and preventative countermeasures using AHP incorporated with GIS in Lanzhou, China. Sustain. https://doi.org/10.3390/su10020304

Lyu, H.M., Shen, S.L., Yang, J., Yin, Z.Y., 2019a. Inundation analysis of metro systems with the storm water management model incorporated into a geographical information system: A case study in Shanghai. Hydrol. Earth Syst. Sci. https://doi.org/10.5194/hess-23-4293-2019

Lyu, H.M., Shen, S.L., Zhou, A., Yang, J., 2019b. Perspectives for flood risk assessment and management for mega-city metro system. Tunn. Undergr. Sp. Technol. 84, 31-44. https://doi.org/10.1016/j.tust.2018.10.019

Lyu, H.M., Shen, S.L., Zhou, A.N., Zhou, W.H., 2019c. Flood risk assessment of metro systems in a subsiding environment using the interval FAHP-FCA approach. Sustain. Cities Soc. https://doi.org/10.1016/j.scs.2019.101682

Lyu, H.M., Xu, Y.S., Cheng, W.C., Arulrajah, A., 2018b. Flooding hazards across Southern China and prospective sustainability measures. Sustain. https://doi.org/10.3390/su10051682

Ministry of Water Resources of the People's Republic of China, 1999. Hydrological Information Annual Report 1998. China Water\&Power Press. (in Chinese)

Mo, J., Jia, L., Yanlan, L., Chen, Y., 2010. GIS-based Sensitivity Assessment on Environment of Developing Flood Hazards in Guangxi Province. J. catastrophology 25, 33-37. (in Chinese)

Mohamed Elmoustafa, A., 2012. Weighted normalized risk factor for floods risk assessment. Ain Shams Eng. J. https://doi.org/10.1016/j.asej.2012.04.001

Newton, A., Weichselgartner, J., 2014. Hotspots of coastal vulnerability: A DPSIR analysis to find societal pathways and responses. Estuar. Coast. Shelf Sci. https://doi.org/10.1016/j.ecss.2013.10.010

Petit-Boix, A., Arahuetes, A., Josa, A., Rieradevall, J., Gabarrell, X., 2017. Are we preventing flood damage ecoefficiently? An integrated method applied to post-disaster emergency actions. Sci. Total Environ. https://doi.org/10.1016/j.scitotenv.2016.12.034

Saaty, T.L., 1977. A scaling method for priorities in hierarchical structures. J. Math. Psychol. https://doi.org/10.1016/0022-2496(77)90033-5

State Flood Control and Drought Relief Ministry of Water Resources of the People's Republic of China, 2016. Bulletin of Flood and Drought Disasters in China 2016. China Water Power Press. (in Chinese)

State Flood Control and Drought Relief Ministry of Water Resources of the People's Republic of China, 2008. Bulletin of Flood and Drought Disasters in China 2008. China Water Power Press. (in Chinese) 
Sundermann, L., Schelske, O., Hausmann, P., 2014. Mind the risk - A global ranking of cities under threat from natural disasters. Switzerland, Zurich.

Takar, A.A., Dobrowolski, J.P., Thurow, T.L., 1990. Influence of grazing, vegetation life-form, and soil type on infiltration rates and interrill erosion on a Somalian rangeland. J. Range Manag. https://doi.org/10.2307/4002350

UNISDR, CRED, 2015. The human cost of weather-related disasters 1995-2015, UNISDR Publications. https://doi.org/10.1017/CBO9781107415324.004

Van Steenbergen, N., Ronsyn, J., Willems, P., 2012. A non-parametric data-based approach for probabilistic flood forecasting in support of uncertainty communication. Environ. Model. Softw. 33, 92-105. https://doi.org/10.1016/j.envsoft.2012.01.013

Wang, Y., Li, N., Wang, S., Wang, J., Zhang, N., 2019. Development and application of flood damage assessment system. J. Hydraul. Eng. 1-8. https://doi.org/10.13243/j.cnki.slxb.20190350

WMO, 1999. Comprehensive Risk Assessment for Natural Hazards - Technical Document 955. https://doi.org/10.1002/9781118281116

Zahran, S., Brody, S.D., Peacock, W.G., Vedlitz, A., Grover, H., 2008. Social vulnerability and the natural and built environment: A model of flood casualties in Texas. Disasters. https://doi.org/10.1111/j.14677717.2008.01054.x

Zeleňáková, M., Fijko, R., Labant, S., Weiss, E., Markovič, G., Weiss, R., 2019. Flood risk modelling of the Slatvinec stream in Kružlov village, Slovakia. J. Clean. Prod. 212, 109-118. https://doi.org/10.1016/j.jclepro.2018.12.008

Zhao, P., Yang, S., Yu, R., 2010. Long-Term Changes in Rainfall over Eastern China and Large-Scale Atmospheric Circulation Associated with Recent Global Warming. J. Clim. https://doi.org/10.1175/2009jcli2660.1

Zhao, Y., Liu, F., Li, Y., 2000. Analysis if Formating Flood Cause and Counter measures of Preventing or Reducing Natural Disaster in 1998. HEILONGJIANG Meteorol. 2, 5-8+11. https://doi.org/DOI:10.14021/j.cnki.hljqx.2000.02.002

Zhou, Q., 2013. Study on Relationship Between Soil Erosion and Shallowlandslides in the Loess Gully Region. Lanzhou University. (in Chinese)

Zhou, Y. xi, Liu, G. jun, Fu, E. jiang, Zhang, K. fei, 2009. An object-relational prototype of GIS-based disaster database, in: Procedia Earth and Planetary Science. https://doi.org/10.1016/j.proeps.2009.09.163 